\title{
Inter-laboratory comparison of cell lines for susceptibility to three viruses: VHSV, IHNV and IPNV
}

\author{
Ellen Lorenzen ${ }^{1, *}$, Bendix Carstensen $^{2, * *}$, Niels Jørgen Olesen ${ }^{1}$ \\ ${ }^{1}$ Danish Veterinary Laboratory, EU Reference Laboratory for Fish Diseases, Hangovej 2, DK-8200 Århus N, Denmark \\ ${ }^{2}$ Steno Diabetes Center, Niels Steensenvej 2, DK-2820 Gentofte, Denmark
}

\begin{abstract}
Eleven European National Reference Laboratories participated in an inter-laboratory comparison of the susceptibility of 5 selected cell lines to 3 fish pathogenic viruses. The test included viral hemorrhagic septicaemia virus (VHSV), infectious hematopoietic necrosis virus (IHNV) and infectious pancreatic necrosis virus (IPNV), and the cell lines derived from bluegill fry (BF-2), chinook salmon embryo (CHSE-214), epithelioma papulosum cyprini (EPC), fathead minnow (FHM) and rainbow trout gonad (RTG-2). The results showed that for isolation of VHSV, BF-2 and RTG-2 cells performed equally well and had higher sensitivity compared to the other cell lines. For IHNV, EPC and FHM cells gave the best results, and for IPNV it was BF-2 and CHSE-214 cells. FHM cells showed the largest variability among laboratories, whereas EPC was the cell line showing the smallest variability.

KEY WORDS: VHSV IHNV - IPNV $\cdot$ CHSE-214 FHM EPC $\cdot$ BF-2 $\cdot$ RTG-2 C Cell line susceptibility Inter-laboratory comparison
\end{abstract}

\section{INTRODUCTION}

Viral hemorrhagic septicaemia (VHS) and infectious hematopoietic necrosis (IHN) are both widespread diseases in Europe causing serious losses in reared rainbow trout Oncorhynchus mykiss. In North America, VHSV has been demonstrated in marine fish species callected along the northern Pacific coast, and IHNV occurs endemically among rainbow trout cultured in some areas of ldaho, USA, and among anadromous salmonid stocks inhabiting rivers of the Pacific coast. Both diseases are caused by viruses belonging to a newly approved genus, Novirhabdovirus (Gael Kurath, Western Fisheries Research Center, pers. comm.), within the Rhabdoviridae. In many European countries, survey programmes for VHS and IHN have been established, and some of these include a formal con-

\footnotetext{
·E-mail:el@svs.dk

- For the statistical analysis the interested reader can obtain a report with a detailed account by contacting the second author.E-mail:bxc@novo.dk.
}

tract with the EU Commission. In several areas within the EU, VHS- and/or IHN-free zones have been approved after 4 or more yr of surveillance. The effectiveness of a survey relies considerably upon the training of the veterinary inspectors, who must observe fish for clinical signs, as well as upon the sensitivity and precision of the diagnostic procedures applied in the laboratories. The guidelines for the frequency of clinical inspections, collection of samples and performance of virological examinations in the laboratory needed to establish an approved survey program were first laid down in the Commission Decision 92/532/EEC (1992) and recently amended by $96 / 240 / E C$ (1996). According to these Commission Decisions, isolation of virus by cultivation is necessary in order to determine that fish are infected by VHSV or IHNV. However, a number of cell lines are commonly used for isolation of both viruses, i.e. BF-2 (fibroblast cell line from caudal trunk of bluegill Lepomis macrochirus fry; Wolf et al. 1966), RTG-2 (fibroblast cell line from rainbow trout gonad; Wolf \& Quimby 1962), CHSE-214 (epitheloid cell line from chinook salmon Oncorhynchus tshawytscha 
embryo; Fryer et al. 1965), FHM (epitheloid cell line from fathead minnow Pimephales promelas; Gravell \& Malsberger 1965) and EPC (epitheloid cell line from epithelial papuloma of common carp, i.e. Cyprinus carpio; Fijan et al. 1983, Wolf 1988, Olesen \& Jørgensen 1992).

Only 1 or 2 passages on a given cell line are thought to be enough to alter the infectivity of a certain virus for other cell lines (experience from authors' laboratory). The relative sensitivity of various cell lines for virus isolation therefore is still disputed and no adequate comparative study including naturally infected material for primary isolation has yet been undertaken to the authors' knowledge. According to Commission Decision 92/532/EEC(1992), the BF-2 and either the EPC or FHM cell lines should be used for isolation of VHSV or IHNV. However, during a workshop held at the Danish Veterinary Laboratory (DVL) in Århus, Denmark, in November 1994 for all EU National Reference Laboratories, it was intensively discussed which cell lines were the most appropriate for isolation of VHSV and IHNV, and, if sensitivity of certain fish cell lines differed among laboratories.

In order to clarify these questions, an inter-laboratory comparative test was initiated in 1995 by the EU Reference Laboratory that included 11 European laboratories. Tissue material from rainbow trout Oncorhynchus mykiss naturally infected by either VHSV, IHNV or infectious pancreatic necrosis virus (IPNV) was titrated on BF-2, CHSE-214, EPC, FHM and RTG-2 cells. IPNV was included because the virus is widespread and several countries have established survey programs for IPN. The results indicated that the BF-2 and RTG-2 were the most sensitive cell lines for isolation of VHSV, EPC and FHM for IHNV, and BF-2 and CHSE-214 for IPNV.

\section{MATERIALS AND METHODS}

Tissue material. Tissue pools of kidney and spleen specimens from rainbow trout naturally infected by VHSV (serogroup III, Olesen et al, 1993) or IPNV (serotype $\mathrm{Sp}$ ) were collected from farms in Denmark that had recently had an outbreak of VHS or IPN, respectively. All sampled fish had clinical signs of disease. Material from fish infected under experimental conditions (immersion) with a Danish reference strain of VHSV (3592B, serogroup I) was also included. Likewise, specimens from rainbow trout reared at an approved VHS-, IHN- and IPN-free fish farm were used as negative controls. The tissue material was processed according to standard procedures following 92/532/EEC (1992) guidelines. Briefly, the tissue specimens were homogenized using mortars, pestles and sterile quartz sand and diluted 1:10 in cell culture medium (Eagle's MEM [EMEM] supplemented with $10 \%$ foetal bovine serum [FBS], Tris buffer and antibiotics). Following centrifugation at $2500 \times g$ for $15 \mathrm{~min}$ at $4^{\circ} \mathrm{C}$ the supernatant was collected, filter sterilized through $0.45 \mu \mathrm{m}$ membrane filters and transferred to glass vials $\left(0.5 \mathrm{ml} \mathrm{vial}^{-1}\right.$ for ampoules $A, B, C$ and $F$ and $1.0 \mathrm{ml}$ for ampoule D). The vials were frozen at $-80^{\circ} \mathrm{C}$ until lyophilization. Each batch of virus-infected material was Iyophilized separately to avoid cross-contamination. Following lyophilization, the vials were stored at $4^{\circ} \mathrm{C}$ until dispatch. Because Denmark is a zone approved free from IHN, Dr G. Bovo, Istituto Zooprofilattico Sperimentale della Venezie (IZPV), Padova, Italy, was asked to collect, and by similar methods prepare, tissue material from rainbow trout naturally infected with IHN virus. To assess the amount of virus in each batch and to make sure that the tissue material contained the expected virus, and only that virus, representative vials were titrated and if cytopathic effect (CPE) was observed, the virus was identified serologically by means of indirect fluorescence antibody test (IFAT)

The lyophilized material was sent on ice to the 11 laboratories (including DVL) participating in the test. Each laboratory received 10 ampoules, comprising duplicates of the 5 different samples of tissue material coded as follows: virus A (tissue material without virus), virus $B$ (VHSV serogroup I), virus C (IPNV), virus D (IHNV), and virus F (VHSV serogroup III). For the remaining part of the present paper the names of the viruses will be used instead of the codes.

Titration procedure. The laboratories were asked to titrate the material from all 10 vials on 5 cell lines within 3 mo after receipt. The following cell lines were included: BF-2, RTG-2, CHSE-214, FHM and EPC. To ensure that the titrations were performed in a comparable manner, detailed illustrations and guidelines as briefly outlined below were enclosed: the lyophilized material of the vials was to be resuspended in $2 \mathrm{ml}$ cell culture medium containing $10 \%$ FBS, Tris buffer, and antibiotics. The virus suspension was filter-sterilized by passage through a $0.45 \mu \mathrm{m}$ membrane filter, the filtrate transferred to 96 -well dilution plates (microtitration plates with round bottoms), and 8 successive 10 -fold dilution steps performed, starting with the diluted ampoule material (corresponding to a 1:20 and $1: 40$ dilution of the original tissue material in ampoules with $1 \mathrm{ml}$ and $0.5 \mathrm{ml}$ tissue homogenate, respectively). The dilutions were performed by use of a multichannel pipette and with change of tips between each dilution step. Filtrates from a set of 5 ampoules could, in this way, be diluted on a single plate. Six replicates of each virus dilution were to be inoculated in parallel onto all 5 cell lines using $15 \mu \mathrm{l}$ well $^{-1}$. Cell cultures were to be 
grown in 96-well microtiter plates with each well containing $150 \mu \mathrm{l}$ cell culture medium. The cell cultures, not more than $24 \mathrm{~h}$ old at the time of inoculation, were to be incubated at $15^{\circ} \mathrm{C}$ and examined daily for CPE by microscopy. The final reading was performed following $7 \mathrm{~d}$ of incubation and the results noted on a diagram enclosed and submitted to DVL. Here the titers were calculated as tissue culture infective dose $50 \%\left(\mathrm{TCID}_{50}\right) \mathrm{ml}^{-1}$ tissue homogenate diluted $\times 40$ or $\times 20$ (i.e. the tissue material was firstly diluted 1:10 before lyophilization, and secondly diluted $1: 4$ or $1: 2$ following lyophilization) according to Rovozzo \& Burke (1973). In the present context the 'titer' is thus used as a measure of the relative sensitivity of a certain cell line to a certain virus and not as a measure of the ability of the cell line to produce virus. The participating laboratories were also asked to give some details (i.e. passage number, origin, medium etc.) of the cell lines used.

Identification. When a virus was detected, it was identified at each laboratory using IFAT, enzyme linked immunosorbent assay (ELISA) or neutralization test according to 92/532/EEC (1992).

Statistical analysis. All analyses of data were performed on log-transformed values of the titers. The results from the control tissue material without virus were not included in the analyses. The median value and the range (lowest and highest titer) for each combination of virus and cell line were calculated from the data submitted by all laboratories.

For each combination of virus and cell line, we computed the repeatability and reproducibility according to the ISO 5725 standard (1997). Briefly, these are $95 \%$ prediction intervals for differences between measurements from the same laboratory (repeatability) and between measurements from different laboratories (reproducibility). These can (assuming normally distributed errors) be transformed to probabilities of finding a difference in titer less than $1 \log _{10}$, which has been used as a standard criterion for biologically insignificant differences between titers (Rovozzo \& Burke 1973, McAllister 1997). It should be noted that the replicates in the present study were not true replicates (i.e. 2 replicate measurements of the same ampoule in the same laboratory), but were titrations of the material of duplicate ampoules in the same laboratory. Therefore the estimated repeatabilities may be on the high side.

A combined analysis of the whole data set was done using a linear mixed model (random effects model) with fixed effects of laboratory and virus $x$ cell line and random interaction effects between laboratory and virus and between laboratory and cell line:

$$
\mathrm{E}\left(y_{v c l g}\right)=\mu_{1}+\beta_{v c}+a_{v l}+b_{c l}+e_{v c l g}
$$

with $v$ representing virus, $c$ cell line, $I$ laboratory, and $g$ replicate. The Greek letters refer to fixed effects, the Latin to random effects. From this model, we derived estimates of pairwise laboratory differences, and pairwise differences between virus effects within each cell line and vice versa.

Further, the model was used to assess whether the cell lines had the same variability among the laboratories by plotting the predicted values of $b_{c l}$ against the cell line, the so-called BLUPs (Best Linear Unbiased Predictors). The values $b_{c l}$ represented the values of the laboratory $\times$ cell line effect, which determined the portion of the variation between laboratories that was specific to the cell line. The size of these values indicated whether any one cell line had larger betweenlaboratory variability than others.

In order to display the total variability between laboratories for all cell lines, we computed the average predicted response (BLUP) for each combination of laboratory and cell line, averaged over all viruses tested:

$$
\mu_{l}+b_{c l}+\sum_{v}\left(\beta_{c v}+a_{v l}\right) / 4
$$

These quantities gave the predicted laboratory differences for each cell line (i.e. the total laboratory $x$ cell line interaction). For further details on the statistical analyses, the reader is referred to Littell et al. (1996)

\section{RESULTS}

All participating laboratories performed the test within the time schedule, and all laboratories except 2 identified the virus in each ampoule correctly. Two laboratories reported more than 1 virus (VHSV and IHNV) in some ampoules or reported viruses present in negative control material (data not shown). However, subsequent examination of the remaining ampoules at DVI confirmed that the samples had not been cross-contaminated before they were forwarded to the participating laboratories. A preliminary analysis of the data is presented in Table 1 as the median and range of the titers $\left(\log _{10}\right.$ of the titers). It can be seen from the table that in a few laboratories, certain viruses could not be detected on some cell lines as demonstrated by the fact that the lower range number is 0.00, as for VHSV-I on FHM and CHSE-214 cells, IPNV on EPC, RTG-2 and FHM cells, IHNV on FHM cells and VHSV-III on CHSE-214-cells. One laboratory had problems with FHM cells and could therefore not report any results for this cell line, which was accounted for in the data analysis. Most laboratories used EMEM supplemented with 10\% FBS, 3 used the Glasgow modification of MEM (GMEM) and 1 laboratory used Leibowits (L15), only for the RTG-2 cells. 
Table 1 Median, minimum (min) and maximum (max) titration values ( $\log _{10}$ hereof) including results from all 11 laboratories

\begin{tabular}{|c|c|c|c|c|c|c|c|c|c|}
\hline \multirow{3}{*}{ Cell line } & & & & & \multirow{3}{*}{ Virus } & \multirow{2}{*}{\multicolumn{2}{|c|}{ VHSV-III }} & \multirow{2}{*}{\multicolumn{2}{|c|}{ IPNV }} \\
\hline & \multicolumn{2}{|c|}{ IHNV } & \multicolumn{2}{|c|}{ VHSV-I } & & & & & \\
\hline & Median & Min, $\max$ & Median & Min, $\max$ & & Median & Min, $\max$ & Median & $\operatorname{Min}, \max$ \\
\hline $\mathrm{BF}-2$ & 3.66 & $2.32,6.16$ & 4.16 & $2.16,6.32$ & & 5.74 & $3.49,7.32$ & 5.24 & $1.66,6.32$ \\
\hline RTG-2 & 4.07 & $2.66,6.49$ & 3.82 & $2.32,5.66$ & & 5.74 & $4.32,7,16$ & 3.55 & $0.00,5.82$ \\
\hline CHSE-214 & 3.49 & $2.16,6.16$ & 3.57 & $0.00,6.32$ & & 4.24 & $0.00,7.16$ & 5.40 & $2.32,7.99$ \\
\hline FHM & 4.91 & $0.00,7.16$ & 3.40 & $0.00,6.16$ & & 4.32 & $1.48,7.66$ & 2.90 & $0.00,5.49$ \\
\hline EPC & 5.16 & $3.49,6.16$ & 2.66 & $2.16,4.32$ & & 4.15 & $2.32,6.16$ & 3.32 & $0.00,6.16$ \\
\hline
\end{tabular}

\section{Repeatability and reproducibility}

In Table 2, the repeatabilities ( $r$ ) and reproducibilities $(R)$ are shown together with the probabilities of a nonsignificant difference, calculated for each virus $\times$ cell line. The within laboratory variation $(r)$ was generally small, with probabilities $(\pi)$ of identical samples giving non-significantly different results (i.e. differences less than $1 \log _{10}$ ) very close to 1 . The picture is somewhat more variable for the data describing between laboratory variation $(R)$, where the probability for nonsignificant differences was highest for EPC and RTG-2 cell lines, and lowest for the FHM cell line. For all cell lines, the probability for a non-significant difference between laboratories was remarkably low for IPNV.

\section{Virus $\times$ cell line interaction}

The effect of the interaction between virus and cell line is presented by virus and by cell line in Fig. 1. The absolute value of the scale is arbitrary, because only the relative size of the interaction is relevant. The scale is $\log _{10}$ (maximal titration) so a doubling of the response corresponds to a difference of $\log (2)=0.3010$ in this scale. The boxes illustrate the non-significant differences, and accordingly for a given virus, the cell lines within the same box were equally sensitive for detection of that particular virus, whereas cell lines not in the same box had significantly different sensitivity, using a significance level of 0.05 . Thus for the VHS viruses I and III, BF-2 and RTG-2 cells were equally sensitive, whereas FHM and EPC cells had significantly lower sensitivities and CHSE-214 cells had a lower sensitivity to serogroup III and an intermediate sensitivity to serogroup I. For IHNV, EPC cells gave higher titers than all the other 4 cell lines, with FHM cells being not significantly lower, whereas RTG-2 cells were significantly less sensitive, and BF-2 and CHSE-214 the least sensitive. For IPNV, CHSE-214 and BF-2 were significantly more sensitive than RTG-2 and EPC cells, and FHM cells gave the lowest titer.

\section{Laboratory effect}

The systematic effect of the laboratory on the performance of the cell line independent of the virus is presented in Fig. 2. Both the pure random laboratory $x$ cell line interaction (Fig. 2a) as well as this effect combined with the fixed laboratory effect (Fig. 2b) is presented. From the display of the pure laboratory $\times$ cell line interaction it is clear that there is no systematic pattern, e.g. certain laboratories scoring unusually high on particular cell lines. When the laboratory effect is included, the differences between laboratories clearly show up, dividing the laboratories in 2 almost disjoint groups, leaving the response pattern for each laboratory almost unchanged. This shows that the laboratory effects in general affect all cell lines. The figure reflects the homogeneity of variability of each of the

Table 2. Repeatability $(r)$ and reproducibility $(R)$ according to ISO 5725 (1997) and probabilities that 2 measurements are within $1 \log _{10}$ (titer) of each other within $(\pi)$ respectively between (II) laboratories, for all combinations of virus and cell. line

\begin{tabular}{|llcccc|}
\hline Virus & Cell line & $r$ & $R$ & $\pi$ & II \\
\hline IHNV & BF-2 & 1.79 & 2.41 & 0.887 & 0.759 \\
& CHSE-214 & 2.57 & 2.87 & 0.729 & 0.676 \\
& EPC & 1.83 & 1.84 & 0.879 & 0.876 \\
& FHM & 2.22 & 4.93 & 0.798 & 0.434 \\
& RTG-2 & 2.04 & 2.24 & 0.835 & 0.794 \\
IPNV & BF-2 & 0.75 & 4.28 & 1.000 & 0.491 \\
& CHSE-214 & 1.03 & 4.50 & 0.994 & 0.470 \\
& EPC & 1.17 & 4.54 & 0.984 & 0.467 \\
& FHM & 1.33 & 5.97 & 0.966 & 0.364 \\
RTG-2 & 1.28 & 5.33 & 0.973 & 0.404 \\
VHSV-I & BF-2 & 1.82 & 2.64 & 0.880 & 0.717 \\
& CHSE-214 & 1.65 & 4.26 & 0.913 & 0.494 \\
& EPC & 1.32 & 2.01 & 0.967 & 0.840 \\
& FHM & 2.03 & 4.99 & 0.837 & 0.429 \\
RTG-2 & 1.77 & 2.97 & 0.889 & 0.660 \\
VHSV-III & BF-2 & 1.74 & 3.09 & 0.895 & 0.640 \\
& CHSE-214 & 1.48 & 5.80 & 0.944 & 0.374 \\
& EPC & 1.11 & 2.96 & 0.989 & 0.660 \\
& FHM & 1.12 & 4.75 & 0.988 & 0.448 \\
RTG-2 & 1.13 & 2.48 & 0.988 & 0.746 \\
\hline
\end{tabular}


Fig. 1. Interactions of virus and cell line. The scale is $\log _{10}$ (titer), so a difference on this of $0.3010=$ $\log _{10}(2)$ corresponds to a doubling of the titer. Interactions are plotted by (a) virus, and by (b) cell line Estimates that are not significantly different at the $5 \%$ level are boxed together

5 cell lines among the 11 laboratories. It appears, however, that the EPC and RTG-2 cells did not differ significantly among the laboratories, whereas BF-2 and CHSE-214 varied more, and FHM cells showed the largest variability.

\section{DISCUSSION}

The results demonstrated that for isolation of virus from tissue material, BF-2 or RTG-2 cells should be the cell lines of choice for VHSV, while EPC or FHM cells should be used for IHNV, and CHSE-214 or BF-2 for IPNV. These findings led to a decision to extend the Commission Decision 92/532/EEC

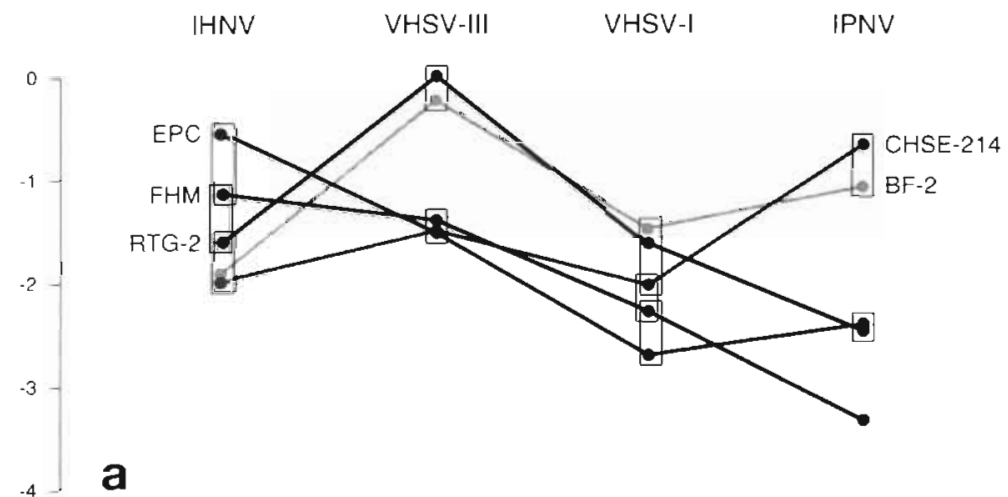

RTG-2 BF-2 CHSE-214 FHM EPC

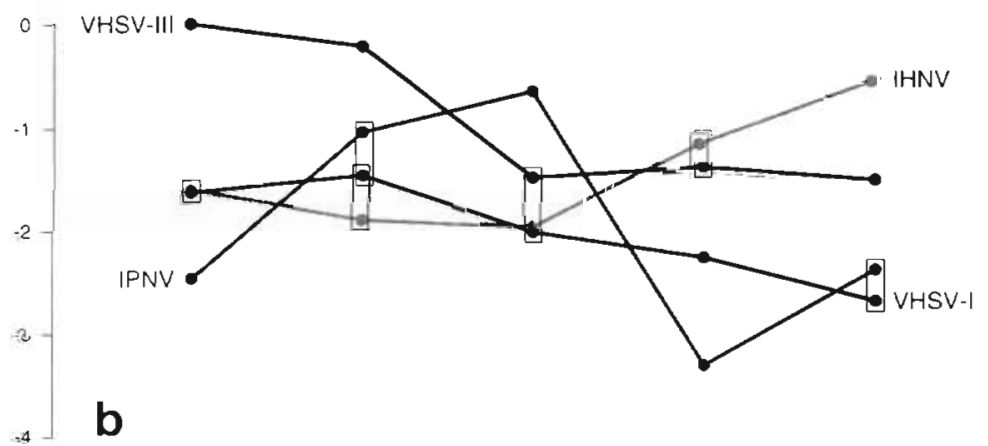

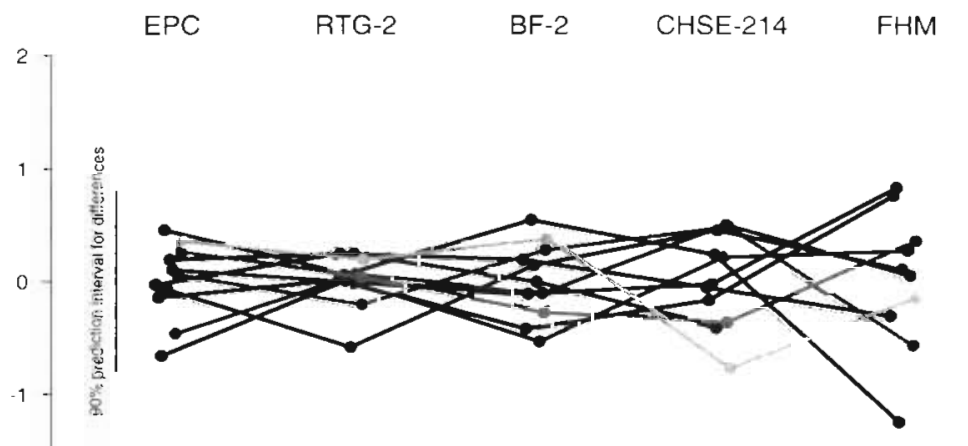

a Random $\mathrm{L} \times \mathrm{C}$ effeci only

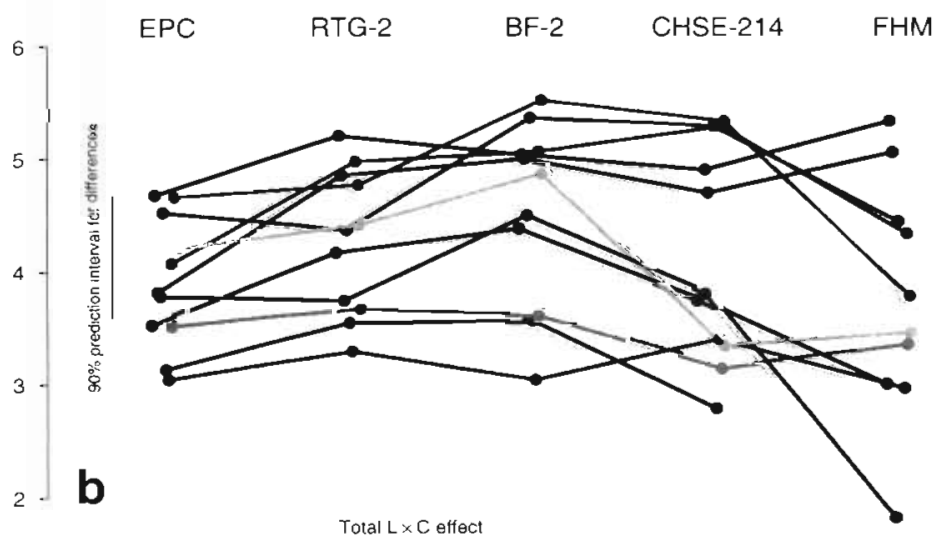

(1992), allowing examination of fish tissue material for the presence of VHSV and IHNV on either BF-2 or RTG-2 cells and either EPC or FHM cells, which are the terms of the amended Commission Decision 96/240/EC (1996). Because RTG-2 cells showed less variation among laboratories compared to BF- 2 cells and turned out to be equally fit for cultivation of VHSV, the matter of dispute of the EU-workshop in 1994 , where doubt was raised about the suitability of RTG-2 cells compared to BF-2, was resolved. The possibility cannot be excluded that use of other techniques, media, buffers, etc., may give different results. However, this is another study. In the present study no apparent tendencies for laboratories using GMEM were observed compared to the ones using EMEM.

Fig. 2. Laboratory effects from the random effects model (Eq. 1). (a) Best Linear Unbiased Predictors (BLUPs) of the pure laboratory by cell line interactions $\left(b_{c l}\right)$. (b) BLUPs of the total predicted laboratory effects averaged over viruses (Eq. 2). (Data points from the same laboratory are connected. Points from different laboratories are slightly horizontally offset to improve readability.) L.: laboratory; C: cell line 
Generally, it was demonstrated that all cell lines except for FHM behaved in a comparable manner between the participating laboratories. However, FHM came out as the second choice after EPC cells for detection of IHNV (on line with RTG-2 cells), and therefore there was no need for changing the Commission Decision on that point. For isolation of IHNV, others have reported that FHM cells were more sensitive than RTG-2 (Amend et al. 1969), which justifies its position as an alternative to EPC. In a study by Fendrick et al. (1982), EPC and FHM cell lines were also found to be superior to CHSE-214 and RTG-2 as regards isolation of IHNV from infected tissue material. However, Yoshinaka et al. (1997) reported that the RTG-2 cell line was less susceptible to toxic substances in ovarian fluid compared to FHM and EPC cells, and that it was equally sensitive to IHNV. The large variability in virus sensitivity of the FHM cells among the laboratories reflected in Fig. 2 is also seen in Table 1, where at least 1 laboratory did not observe any CPE for 3 of the viruses on FHM cells. In addition, 1 laboratory was not able to make FHM cells grow in a satisfactory manner and therefore could not report any data for that cell line at all. FHM cells have been described in the literature as being difficult to handle as they may have a tendency to slough from the growing surface (Kelly et al. 1978). Among the laboratories that were able to grow FHM cells, however, IHNV generally gave high titers. FHM cells were also shown to be superior to CHSE-214 and RTG-2 cells when inoculated with IHN-virus harvested from RTG-2 cells in the study by Kelly et al. (1978).

Other reported studies on the relative susceptibility of fish cell lines to VHSV, IHNV and IPNV confirmed the present results. Using cell culture grown virus, CHSE-214 were highly sensitive to IPNV (Lannan et al. 1984, Yoshimizu et al. 1988) and for IHNV, EPC cells gave good response (Yoshimizu et al, 1988, Batts \& Winton 1989). Using tissue material, Kelly et al. (1978) found that RTG-2 cells were more sensitive to IPNV than FHM cells.

According to Table 1, all viruses could be detected on all of the 5 cell lines. The material for the present trial consisted of organ samples from fish with clinical signs of the respective virus infections and thus relatively high titers would be expected. However, Commission Decision 96/240/EC (1996) does not only deal with isolation of virus from fish with overt infections, but also with survey programmes, where most of the sampled fish are not infected or covertly infected. The present trial does not tell anything about which cell lines are most appropriate for demonstration of carriers of VHSV, IHNV and IPNV, but it may be reasonable to assume that the cell lines giving the best results in the present study would also be the most sensitive when dealing with material having a low concentration of virus. This was demonstrated in a previous study by Olesen \& Jørgensen (1992) where BF-2 cells were shown to be superior to EPC and CHSE-214 cells for isolation of VHSV from clinically infected fish as in the present study, but also from fish without disease signs.

It has been found that at least some fish cell lines may lose susceptibility to certain viruses over time, and consequently it is necessary to determine their sensitivity to the relevant viruses at regular intervals (Wolf 1988), according to the recommendations outlined in $96 / 240 / \mathrm{EC}$ (1996). Therefore, the present results should not be regarded as the final word in this case, as some of the cell lines, i.e. the FHM cells, which showed large variability among laboratories, may have become more or less refractory to 1 or more viruses in some of the participating laboratories. For these reasons it is recommended to use a low passage number of cell lines, either by keeping frozen stocks or by receiving cell cultures from other laboratories from time to time. In addition to sensitivity check, cell lines should also be examined regularly for mycoplasma infection (Wolf 1988), which can influence the sensitivity to virus. Development of cell lines with different characteristics as regards virus sensitivity due to different culture conditions and high passage number etc. in different laboratories was also demonstrated by Batts et al. (1991) for EPC and CHSE-214 cells. They found that the titer of VHSV virus differed more than 100-fold (corresponding to 2 on the $\log _{10}$-scale used in the present study) comparing titers on CHSE-214 cells from 4 different laboratories, whereas the difference for IHNV was less than 10-fold. For EPC cells the difference was less than 10-fold for VHSV as well as IHNV. This finding of a higher degree of homogeneity of EPC cells is in accordance with the present results. Titers of VHSV and IHNV also differed significantly among 12 lineages of CHSE-214 cells compared by McAllister (1997), which is in good agreement with the present results where the CHSE-214 cell line had the highest variability between laboratories after FHM cells (Table 2, Fig. 2).

In a recent study, Winton \& Batts (pers. comm.) collected lineages of EPC, CHSE-214, FHM and other cell lines from different national laboratories in the USA for comparison of sensitivity to IHNV, VHSV, IPNV and chum salmon reovirus (CSV). They included open inoculation as in the present study as well as an assay for plaquing efficiency and found that the results from the 2 tests differed, but were comparable. The goal of the study was to compare the detection efficiency of cell lines from different laboratories, to screen the cells for mycoplasma infection, and to expand the best performing, mycoplasma-free cells for distribution to all participating laboratories, which should discard their 
existing stocks of the lines. The exercise would then be repeated regularly. This strategy may also be an alternative means of making results among laboratories more uniform within the EU.

It may be of concern that the variability among laboratories is large, i.e. more than 100 -fold or $2 \log _{10}$ as shown in Tables $1 \& 2(R, I I)$ and Fig. $2 b$. However, even if the ampoules titrated at DVL at different time points gave comparable titers, the ampoules that arrived at the European national reference laboratories may have been subjected to unfavourable temperatures during prolonged transportation, which may have lowered the titers. Ampoules that were stored at room temperature and exposed to sunlight for more than 6 mo at DVL did not contain any live virus except for small amounts of IPNV (ampoule C). By collecting cell lines from the European laboratories and performing the sensitivity test at the EU reference laboratory, the possible bias due to transportation would be overcome. In any case, the large inter-laboratory variability demonstrated stresses the need for establishment of a common quality control program within the EU. Possible guidelines for a quality control program for fish cell lines has already been suggested by Lannan (1994), including handling of cell lines, quality control of reagents and control of contamination.

Batts et al. (1991) also compared sensitivity of different cell lines to European and American strains of VHSV and found that FHM cells had much lower sensitivity to European VHSV, whereas the sensitivity to American VHSV was comparable to that of EPC. On the contrary, RTG-2 cells had more than an order of magnitude lower sensitivity to the American VHSV, whereas the sensitivity to European VHSV was similar to that of EPC cells. These findings may be highly relevant in the light of the recent findings of VHSV in the marine environment around Scotland and Denmark, as the marine VHSV apparently differs from VHSV isolated from farmed fish in freshwater (Mortensen et al. in press), and isolates of marine VHSV seem to consist of a few major subgroups (Snow et al. in press).

The finding of virus in negative control samples by some laboratories focused on the problem that even relatively simple virus cultivation tests can result in false positive reactions. This problem has not been taken into account in the EU Council Directive 91/67/EEC (1991) or in the OIE Diagnostic Manual for Aquatic Animal Diseases (Blancou \& Hastein 1997). At subsequent revisions of the 2 guidelines, the problem of false positive reactions should be considered (e.g. by including the possibility of retesting tissue samples or resampling the fish farm if no epizootiological evidence of the diseases has been observed) before final conclusions as regards infection on a farm are made. It should also be mentioned that an inter-laboratory test where virus infected material and negative control material were handled side-by-side in microtitration plates is not directly comparable to routine diagnostic procedures where material from different sources should be completely separated.

In conclusion, it seems evident from the literature and from the present inter-laboratory testing that fish cell lines may vary as regards virus susceptibility, and therefore in case of a survey for 2 viruses like VHSV and IHNV it is recommended that 2 different cell lines are included. In addition, the cell lines used should be examined frequently for mycoplasma and regularly (e.g. annually) with respect to susceptibility to the relevant viruses as they are biological entities that may change over time and this argues for some kind of quality control program to harmonize virological examinations within the EU.

Acknowledgements. Dr Guiseppe Bovo, Istituto Zooprofilattico Sperimentale delle Venize, Padova, Italy, is deeply acknowledged for contributing lyophilized material containing IHNV to the present test. The following laboratories that participated in the test are greatly acknowledged for their contributions: In Finland Dr Hannele Tapiovara from The National Veterinarian and Food Research Institute in Helsinki; in France Dr Anne-Marie Hattenberger and Dr Jeanette Castric from CNEVA in Maisons Alfort and Brest, respectively; in Germany Dr Peter-Joachim Enzmann and Dr R. Riebe from the Federal Research Centre for Virus Diseases of Animals in Tubingen and the Insel Riems, respectively; in Italy Dr Guiseppe Bovo from Istituto Zooprofilattico Sperimentale delle Venezie in Padova; in Sweden Dr Anders Hellström from The National Veternary Institute in Uppsala; in Norway Dr Birgit Dannevig from the National Veterinary Institute in Oslo; in England Dr Peter Dixon from MAFF in Weymouth, Dorset; in Scotland Dr David Smail from the Marine Laboratory in Aberdeen. Mrs Mette Eliassen from The Danish Veterinary Laboratory is greatly acknowledged for the skillful technical assistance producing the lyophilized material containing VHSV and IPNV and no virus, and for testing the ampoules. Finally, Dr Jim Winton, NW Biological Science Center, Seattle, USA, is deeply acknowledged for constructive and critical comments on the manuscript

\section{LITERATURE CITED}

Amend DF, Yasutake WT, Mead RW (1969) A hematopoietic virus disease of rainbow trout and sockeye salmon. Trans Am Fish Soc 4:796-804

Batts WN, Winton JR (1989) Enhanced detection of infectious hematopoietic necrosis virus and other fish viruses by pretreatment of cell monolayers with polyethylene glycol. J Aquat Anim Health 1:284-290

Batts WN, Traxler GS, Winton JR (1991) Factors affecting the efficiency of plating for selected fish rhabdoviruses. In: Proceedings of the second international symposium on viruses of lower vertebrates. Oregon State University Press, Corvallis, Oregon, p 17-24

Blancou J, Hastein $T$ (eds) OIE diagnostic manual for aquatic animal diseases, 2nd edn (1997) Office International des Epizooties, Paris 
Fendrick JL, Groberg WJ Jr, Leong JC (1982) Comparative sensitivity of five fish cell lines to wild type infectious haematopoietic necrosis virus from two Oregon sources. J Fish Dis 5:87-95

Fijan N, Sulimanovic D, Bearzotte $M$, Muzinic D, Zwillenberg LO, Chilmonczyk S, Vautherot JF, de Kinkelin P (1983) Some properties of the epithelioma papulosum cyprinid (EPC) cell line from carp Cyprinus Carpio. Ann Virol (Inst Pasteur) 134E:207-220

Fryer JL, Yusha A, Pilcher KS (1965) The in vitro cultivation of tissue and cells of Pacific salmon and steelhead trout. Ann NY Acad Sci 126:566-586

Gravell M, Malsberger RG (1965) A permanent cell line from the fathead minnow (Pimephales promelas). Ann NY Acad Sci 126:555-565

ISO 5725 standard (1997) Accuracy (and trueness and precision) of measurement methods and results. Part 1 . General principles and definitions. Part 6 . Use in practice of accuracy values. Geneva

Kelly RK, Souter BW, Miller HR (1978) Fish cell lines: comparison of CHSE-214, FAM., and RAG-2 in assaying IHN and IPN viruses. J Fish Res Board Can 35:1009-1011

Lannan CN (1994) Fish cell culture: a protocol for quality control. J Tissue Cult Methods 16:95-98

Lannan CN, Winton JR, Fryer JL (1984) New cell lines: fish cell lines: establishment and characterization of nine cell lines from salmonids. In Vitro 9:671-676

Littell RC, Milliken GA, Stroup WW, Wolfinger RD (1996) SAS system for mixed models. SAS Institute, Cary, NC

McAllister PE (1997) Susceptibility of 12 lineages of chinook salmon embryo cells (CHSE-214) to four viruses from salmonid fish: implications for clinical assay sensitivity. J Aquat Anim Health 9:291-294

Mortensen HF, Heuer OE, Lorenzen N, Otte L, Olesen NJ (in press) Isolation of viral haemorrhagic septicaemia virus (VHSV) from wild marine fish species in the Baltic Sea, Kattegat, Skagerrak and the North Sea. Virus Res

Olesen NJ, Jørgensen PEV (1992) Comparative susceptibility of three fish cell lines to Egtved virus, the virus of viral haemorrhagic septicaemia (VHS). Dis Aquat Org 12: $235-237$

Editorial responsibility: Jo-Ann Leong.

Corvallis, Oregon, USA
Olesen NJ, Lorenzen N, Jørgensen PEV (1993) Serological differences among isolates of viral haemorrhagic septicaemia virus detected by neutralizing monoclonal and polyclonal antibodies. Dis Aquat Org. 16:163-170

Rovozzo GC, Burke CN (1973) A manual of basic virological techniques. Prentice-Hall Inc, Englewood Cliffs, NJ, p $87-93$

Snow $M$, Cunningham LO, Meloin WT, Kurath $G$ (in press) Analysis of the nucleoprotein gene identifies distinct lineages of viral haemorrhgic septicaemia virus (VHSV) within the European marine environment. Virus Res (in press)

Wolf K (1988) Fish viruses and fish viral diseases. Cornell University Press, Ithaca, NY

Wolf K, Quimby MC (1962) Established eurythermic line of fish cells in vitro. Science 135:1065-1066

Wolf K, Gravell M, Malsberger RG (1966) Lymphocystis virus: isolation and propagation in centrarchid fish cell lines. Science 151:1004-1005

Yoshimizu $M$, Kamei $M$, Dirakbusarakom $S$, Kimura $T$ (1988) Fish cell lines: susceptibility of salmonid viruses In: Kuroda Y, Kurstak E, Maramorosch K (eds) Invertebrate and fish tissue culture. Springer-Verlag, Berlin, p $207-210$

Yoshinaka T, Yoshimizu M, Ezura Y (1997) Selection of suitable cell line for isolation of the infectious hematopoietic necrosis virus (IHNV) from ovarian fluid of salmonid fish Fish Pathol 32:75-80 (in Japanese)

91/67/EEC (1991) Council Directive of 28 January 1991 concerning the anima! health conditions governing the placing on the market of aquaculture animals and products. Off J Eur Comm No. L 46/1-18

92/532/EEC (1992) Commission Decision of 19 November 1992 laying down the sampling plans and diagnostic methods for the detection and confirmation of certain fish diseases. Off J Eur Comm No. L 377/18-26

96/240/EC (1996) Commission Decision of 5 February 1996 amending Decision 92/532/EEC laying down the sampling plans and diagnostic methods for the detection and confirmation of certain fish diseases. Off $J$ Eur Comm No L 79/19-28

Submitted: September 29, 1998; Accepted: April 22, 1999 Proofs received from author(s): July 23, 1999 